\title{
Minar el hilo dorado de la prosa del Estado
}

Franca Maccioni

Instituto de Humanidades, Consejo Nacional de Investigaciones Científicas y Técnicas, Universidad Nacional de Córdoba - Argentina

\section{Resumo}

Este artigo explora os últimos livros poéticos de Martín Rodríguez, focando na relação entre poesia e política, especialmente na própria configuração política da sua poesia. Para isso, refletimos sobre como sua escrita cria uma origem, enquanto noção mítico-infantil do sujeito e histórico-política do Estado, desafiando a continuidade da violência política estruturada desde termos como "ordem, progresso e progressismo".

Palavras-chave: Martín Rodríguez; Imaginação; Política; Origem.

\section{Resumen}

En este artículo proponemos recorrer los últimos libros poéticos de Martín Rodríguez atendiendo a la relación entre poesía y política, específicamente a una política propia de la poesía que allí se propone. Para ello analizaremos el modo como su escritura repone un origen, a la vez, míticoinfantil del sujeto e histórico-político del Estado, impugnando la continuidad de su violencia política fundante estructurada en los términos de "orden, progreso y progresismo".

Palabras clave: Martín Rodríguez; Imaginación; Política; Origen. 
Hay dos clases de personas: los buscadores de originalidady los mineros que se internan en la roca dura de los lugares comunes para extraer algo nuevo. Me afilio a los segundos.

Martín Rodríguez

1. Ellos son: Agua Negra (Siesta, 1999), Natatorio (Siesta, 2001), El Conejo (Deldiego, 2001), Lampiño (Siesta, 2004), Maternidad Sardá (Vox, 2005), Paniagua (Gog y Magog, 2005), Vapor (Vox, 2007), Para el lado de las cosas sagradas (Niño Stanton, 2009), Paraguay (Vox, 2012) y Ministerio de desarrollo social (Determinado Rumor, 2012b).

2. LLACH, Santiago. "Poesía en los noventa: una aproximación", 2006, p. 193.

3. MALLOL, Anahí. "Para una sigilografía de los noventa", 2006, p. 213.
Martín Rodríguez (Buenos Aires, 1978) lleva publicados ya un total de diez libros de poesía ${ }^{1}$. A esto deberíamos sumar sus prolíficas intervenciones ensayísticas y periodísticas en blogs, revistas de política y crítica cultural (Crisis, Panamá, Ni a palos, entre otras) y, en esta línea, el libro de ensayos Orden y progresismo. Los años Kirchneristas (Emecé, 2014).

Si bien en la actualidad su nombre parece haber adquirido mayor visibilidad como crítico político y cultural, su escritura poética no ha pasado desapercibida para la crítica literaria argentina. Son diversas, en este sentido, las intervenciones de críticos de poesía que ubican la producción de Rodríguez dentro de lo que se denominó "poesía de los noventa" y que piensan, desde allí, la específica relación que esta escritura sostiene con lo político. En esta línea, por ejemplo, Daniel Freidemberg vincula ciertas zonas de la poética de Rodríguez a la poesía política argentina de los sesenta.

Santiago Llach, en cambio, la incluye dentro de una amplia generación de poetas que -frente a la crisis política, económica y social que signó la década de los ' 90 y sus años posterioressostuvieron una política de la poesía que consistió en ir a la "raíz de la lengua"2. Anahí Mallol, en una estela similar, propone pensar la escritura de Rodríguez junto a la de otros poetas que -menos cercanos al "realismo sucio" de cierto neobjetivismopropusieron un retorno de lo lírico. Dicho viraje, anuncia Mallol, repercute, también, en el concepto mismo de lo político, en tanto "resitúa la cuestión de la política en su sentido más amplio, que es a la vez el más pequeño: la micropolítica que afecta a los discursos, las enunciaciones, los cuerpos, los constructos teóricos: políticas de los sistemas de pensamiento, políticas de la lengua, políticas de las sexualidades, políticas de la construcción del saber"3.

En la línea de estas intervenciones en este trabajo proponemos abordar los últimos poemarios de Rodríguez poemarios que han sido escasamente abordados por la crítica literaria- en un intento por pensar la politicidad que allí se 
despliega. Lo haremos atendiendo ya no al modo como su escritura se vincula a la de otras poéticas de su generación sino al modo singular que despliega su escritura para disputar un empaste imaginario-político entre violencia, guerra y nación en un intento por proponer un montaje otro de la violencia.
Los últimos poemarios publicados por Martín Rodríguez son políticos en un doble sentido: tienen a la vez un acontecimiento histórico-político como referente y despliegan una politicidad inherente a su procedimiento. Como dijera Marcelo Díaz, sus poemas no sólo "hablan de" acontecimientos histórico-políticos sino que inscriben lo político en la lengua: su escritura hace del "hilo dorado de la prosa de Estado"4 su campo de batalla y avanza, allí, por superposición de imágenes, por contagio, derivando (más que razonando) y reponiendo un origen que no se estabiliza ni se deja estabilizar.

Y decimos "campo de batalla" porque Lampiño (2004), Paniagua (2005), Paraguay (2012) y Ministerio de desarrollo social (2012) podrían ser pensados como cuatro libros de guerra ${ }^{5}$. Cuatro libros de guerra y, al mismo tiempo, cuatro libros cosmogónicos que trazan el origen anfibológico, a la vez mítico (de la vida, de la lengua), e histórico-político, de un mundo (el nuestro). Si tuviéramos que "narrativizarlo" y recuperar su referente explícito podríamos decirlo así: Paniagua delinea la precuela, el enfrentamiento entre "civilización y barbarie" que antecede a la gran guerra de la triple alianza, referente histórico privilegiado del libro Paraguay, como origen del Estado (capitalista y liberal). En esta constelación extraña, podríamos sumar a Lampiño y su referencia velada a la "guerra sucia" de los '70 que, en la historia argentina, culmina, según sugiere Rodríguez en Orden y Progresismo, con una última guerra limpia: Malvinas, ese "gran teatro de despedida de un mundo, de una guerra, de guerrillas, de la guerra fría" de la que los soldados volvieron "sin tierra pero con la democracia arriba del barco". $\mathrm{Al}$ interior de este nuevo orden democrático el último libro, podría pensarse, indica el modo como el orden y el control del territorio continúa ahora como violencia soterrada en una nueva unidad de ejecución: el Ministerio de desarrollo social.

Cuatro libros de guerra, entonces, que hacen de la violencia su tema y su procedimiento, no solo de escritura sino también de lectura de su tiempo. Pero también cuatro "máquinas de guerra" -como dijeran Deleuze y Guattari- que recuperan la guerra (en tanto modo de interiorización estatal de lo marginal)
4. RODRÍGUEZ, Martín. Ministerio de desarrollo social, 2012, p. 11.

5. En este trabajo haremos un uso ampliado del término "guerra". Éste no refiere siempre a una guerra fáctica, al enfrentamiento bélico entre dos o más ejércitos nacionales; funciona, más bien, como matriz de inteligibilidad de la dimensión polémico-violenta de la política que aquí proponemos pensar.

6. RODRÍGUEZ, Martín. Orden y progresismo, 2014, p. 153-154. 
7. NANCY, Jean-Luc. Au fond des images, 2003, p. 99. y su lectura, pero para extraer de allí modos de fuga tanto de la guerra estratégica (soberana y jurídica), cuanto del modo como su lectura inscribe sus conquistas y derrotas al interior de un régimen teológico, teleológico, arborescente y jerarquizado de poder.

Si orden, progreso y progresismo signan en la lengua el triunfo bélico de un orden monológico y de una distribución disciplinada de los cuerpos y las voces, estos tres significantes demarcarán el campo de batalla donde la imaginación poética de Rodríguez ensayará un modo de oponer una política otra de la poesía, de la lengua y del sentido. Como los mineros, Rodríguez se sumerge en la roca dura de la metafísica de nuestra historia nacional (de la historia pensada e impuesta como física, es decir, como natural) para "desensamblar lo que ha sido edificado sobre los principios [y] dejar venir lo que se oculta bajo ellos" Como sugiriera Agamben, su poética signa lo contemporáneo como arcaico, hace la genealogía de los distintos nacimientos (del mundo, del sujeto, del Estado) e indica con su escritura aquel estado heterogéneo, fluido siempre en fuga de la lengua y de los cuerpos que amenaza la estabilidad de cualquier herencia y de cualquier orden disciplinado.

Yo soy lo que bice con lo que el Estado hizo de mí Martín Rodríguez

Como a lo largo de toda la obra de Rodríguez, las imágenes del agua insisten en Paniagua (2005) reponiendo temporalidades heterogéneas del origen: al tiempo que señalan hacia la prenatalidad del niño (hacia esa temporalidad mítica, amniótica) historizan, como dijera M. Laura Romano, la pre-natalidad del Estado argentino. Lo que allí se expone, entonces, es no solo el estadio anterior del sujeto sino también el momento previo al surgimiento del Estado, las luchas que hicieron posible su fundación legislando con su soberanía la libre circulación de los ríos (ahora, del mercado). Lo que era agua-leche se vuelve entonces río aturdido por el vino y la sangre de la historia, de una historia que se escande así: "El alma perdida bajo el agua: era un niño / de hielo, de vapor, sucedía en los estados hasta toparse con el vino / tinto. El río vuelto vino, sangre. Antes que la sangre está el agua. / El vino, la sangre y la leche salen de unas tetas negras. / El paraíso está antes"8.

Ambos relatos cosmogónicos (el del niño y el del Estado)

coinciden en trazar una infancia acuática continua que se ve
8. RODRÍGUEZ, Martín.

Paniagua, 2005, p. 17. 
interrumpida por una misma figura: Paniagua es un libro dedicado al padre, literalmente. Pero de nuevo, no solo a la función paterna que traza la separación, el comienzo del sujeto (de la lengua y la historia) sino también aquella que hace al origen de un mundo histórico-político cuya condición de posibilidad depende, primero, de una imagen singular de "Padre", de un poder modernizador patriarcal ligado a una tecnología privilegiada: la guerra. Lo mítico y lo histórico convergen, entonces, en una imagen común: la de la modernización que llega como un toro que embiste con fuerza guerrera el fluir de lo primitivo:

El vino es el toro que llega y embiste la carcaza. La cigüeña y los perros, parten.

Volando.

La casa de ladrillo vuela por el toro que la embiste.

Construyamos con madera noble,

con roña y canto. La política del vino y del agua chocándose en sus vasos.

Ley seca pero adentro todo mojado. Adentro el vino toro y el agua corriente

siguen su lucha

de civilización y barbarie. ${ }^{9}$

9. Ibídem, p. 21.

La política guerrera y fundante del Estado argentino viene acompañada de un hombre nuevo, de un padre nuevo con "rictus auroral de hijo único, / de rey, / con su ampolla susurrando que es el padre, / que tiene que hachar y talar" ${ }^{10}$. Una nueva configuración subjetiva para la que, como afirma otro de los versos: "La cría / de los hijos como la cría / del ganado como / pisar uvas es arte / menor, para un jefe / de hogar"11. Una modificación encarnada de la subjetividad coincide punto a punto con la emergencia del Estado liberal en el personaje "paniagua" que expone una modificación crucial: "Paniagua: papa celeste al principio. En el primer jardín anti-carnívoro. / El rumor del río de lo esencial y lo mortal, / Paniagua en el umbral de un hombre: su miga amasada ya se parece a la carne"12.

Abandonado el primer jardín anti-carnívoro, la miga amasada de esta nueva subjetividad "ya se parece a la carne", a esa carne de cañón que ahorrará en cuerpo para ganar en progreso con la condición de negar la marca del orden material y sensible de lo somático: "Qué madre. No todo es pezón, hoguera... / Los huevos también tienen su jardín. Sin el burdo / semblante (permanente) de lo sexual, de lo que tiene que ser / atravesado por el rayo de cobre de leche sólida"13. Para esta escritura poética, el Estado y el padre nacen juntos con un jardín otro, una subjetividad otra y un río otro:

10. Ibídem, p. 33.

11. Ibídem, p. 22.

12. Ibídem, p. 17.

13. Ibídem, p. 39.

Las compuertas abiertas del llanto en río revuelto.

Pero acá no se llora. Se llora adonde hay leche.

Este es un jardín de piedras, de árboles (casi) secos. 
14. Ibídem, p. 41.

15. Ibídem, p. 35.

16. Ibídem, p. 53.

17. Ibídem, p. 28.

18. RODRÍGUEZ, Martín.

Paraguay, 2012, p. 30.
Padre con la primera caricia te perdiste en un bosque, llevabas el hacha en una mano

ensangrentada, y en la otra

la caricia como un

temblor epiléptico.

Te hachaste esa mano contra un tronco.

Después hachaste el tronco.

Después te revolviste en el río. ${ }^{14}$

El río se tiñe, entonces, de rojo-sangre y el padre "talla su imagen viril en la moneda endeble, / líquida, inestable, / de los primeros intercambios" $"$. Podemos decir entonces, que Estado y capital nacen al tiempo que lo hace esa subjetividad que sacrifica el cuerpo (suyo y ajeno) en nombre de un nuevo modelo soberano que se construye sobre:

Los talones de los niños que murieron pisando la uva para el padre, día y noche, sin descanso, en el jardín, en el baldío, en el patio de la pensión, en la iglesia, en el campo, en toda hora y lugar para que el padre se tome el vino recién cosechado de la sangre de los niños que creó con el sudor de su sexo. ${ }^{16}$

En el fluir turbulento que va de las imágenes prenatales del agua-leche-semen al vino, del vino a la sangre y de la sangre al río se expone un hilo común: aquel que entreteje la relación necesaria entre una subjetividad occidental paradigmática, un proyecto económico (el del capital) y una tecnología política privilegiada (la guerra). Y “ ¿adónde lleva el río? A una ciudad que está ardiendo"17, a un país de hombres e hijos talados, a la constatación de que "ya no existe el paraguay".

Paraguay (2012) comienza con una imagen fotográfica en blanco y negro que cifra la continuidad de esta cosmogonía anfibológica. Delante de una tienda un señor, más atrás dos niños que no le llegan ni a la cadera nos miran de frente. Los tres comparten el mismo uniforme de guerra. Y de nuevo, entonces, "la historia es simple" y se escande así:

cuando se acabaron los hombres paraguayos / los niños fueron llamados: golpeaban las campanas / como si sirvieran la copa de leche, / bronces / contra / el / tronco: / de las entrañas / de la tierra, como / donaciones de pavas y de anillos, / del fondo arcilloso de las madres, / del talón de ellas que pisaron las últimas flores, los jazmines. ${ }^{18}$

La guerra de la Triple Alianza será entonces el referente histórico privilegiado de este libro. Una guerra que llevó al extremo las consecuencias de esa subjetividad vuelta carne sin cuerpo, decidiéndose por los niños, de un lado, y los esclavos del otro: 
¡Atrás! Negros macacos

con la soga al cuello, jatrás!

que vienen silbando arriba

de sus ponys 3500 niños.

Caxias: la esclavitud es tu brazo armado que amenaza a niños blancos y bilingües.

Frágiles campanitas de llanto amarillo

con las hebras de un té inglés bordados,

en un paraíso de campiña

y de rocío violado,

sus nombres en guaraní. ${ }^{19}$

19. Ibídem, p. 36.

La escritura poética de Paraguay expone en imágenes el punto extremo de complicidad entre una subjetividad cristiana y una subjetividad teológico-política que funda por excepción guerrera sacrificando el cuerpo y sus usos: "la guerra / en su cristiandad simple: la vida es una milicia. / Los niños de esta guerra se llaman Agustín"20. Un combate que opta por el niño que "está mejor preparado / para la guerra / porque sabe / que su cuerpo no le pertenece, / lo cedió / a una fuerza mayor" 21 . $\mathrm{O}$, como afirma este otro poema, que optó por la:

Carne pura del más puro dios, Mariscal.

Ya perdiste la fundición de Ibicuy, la que nació para la obra pública, pero qué mejor obra

pública que la guerra,

obra sobre el temperamento del pueblo

de manera que lo que empieza como entrega

con pavas y campanas

sigue con el infante... ${ }^{22}$

22. Ibídem, p. 51.

Perdida la fundición de hierro de Ibicuy, la guerra toma su lugar y lo que funda es un mundo, este mundo, el mundo que habitamos y del que somos herederos. Y lo funda por fundición. O mejor, la guerra es el espacio-tiempo de una gran fundición y "la fundición es un conventillo de utensilios y creencias"23.

23. Ibídem, p. 16.

"Una vez un país fue a la guerra". Así se titula uno de los poemas que dice: "Argentina fue a la guerra. / Paraguay fue a la guerra. / Brasil fue a la guerra. / Y cada uno fue con todo lo que tenía adentro" 24 . Metales, banderas, niños, creencias, lenguas. En la guerra todo vale por la dureza de su resistencia. "Madres con campanitas colgadas, los anillos dorados, las cruces, / entrando ellas mismas al fuego, y saliendo del fuego / con sus hijos en brazos: / la verdadera joya familiar hirviendo" 25 . Todo fundido para hacer materia de cañón, o como dice otro de los versos para hacer "el elemento de tu moneda" 26 .

20. Ibídem, p. 31.

21. Ibídem, p. 21.

24. Ibídem, p. 53.

25. Ibídem, p. 16.

26. Ibídem, p. 13.

La escritura de este libro se obstina en decirnos que "hay que hacer la guerra para entrar al mundo". "Cada caído una cruz de palo. Bienvenido al mundo"27, así se lee en otro de sus 
28. Ibídem, p. 85.

29. Ibídem, p. 85

30. Ibídem, p. 62.

31. RODRÍGUEZ, Martín.

Orden y progresismo, 2014, p. 152.

32. RODRÍGUEZ, Martín. Paraguay, 2012, p. 17.

33. Ibídem, p. 66.

34. Ibídem, p. 74 versos. ¿No fue acaso eso la guerra de la triple alianza?, ¿una guerra para devolverle el Orden al Caos? O, como se pregunta un poema que lleva por título las palabras de Alberdi: “Existe sobre la tierra autoridad alguna, por justa y liberal que sea, que no haya empezado por ser despótica?" 28 . Y este mismo poema responde luego con claridad. Cito: "Las partes del mundo sin orden ya no son mundo. / El mundo es una idea donde hay países posibles, / pequeños, recolectores, perdidos. / Cada uno expuesto al despotismo de cada uno" 29 y del otro.

En este libro, orden y progreso coinciden en una imagen común: aquella que dibuja la línea de fuego de una bala lanzada al futuro:

El viaje eléctrico del progreso es invisible.

La guerra es una fuerza sobrenatural que encoje los tiempos. De madrugada sólo se ve el campo de batalla iluminado.

Imita a las millones de lamparitas encendidas cien años después. ${ }^{30}$

Entonces, se trató de eso, de una guerra contra los mundos en nombre del mundo, de ese nuevo único mundo mundial y liberal que supo trazarse en el territorio que dibuja la complicidad entre la carne, la guerra y la acumulación de capital. Una gran fundición para ir hacia. Y el problema aquí son las preposiciones. El para, el hacia del cántico guerrero del "último 'marchemos', y el dedo índice apuntando a un lugar porque, de fondo, había que huir hacia adelante" ${ }^{31}$. Y adelante, lo sabemos, no hay nada. El progreso, si aún tiene algún sentido, si lo tuvo alguna vez acaso, sólo ha sido el de justificar la marcha. Y la guerra. Hacia adelante solo resta el territorio que disputamos en el imaginario. Territorio que se figuró virgen, desierto, como la posibilidad inédita de fundar un mundo nuevo. Y quizás sea eso lo único certero sobre la guerra. Conocemos su movimiento pero no sus móviles. O quizás el móvil coincida con el deseo de seguir la marcha hacia un territorio imaginario y nuevo. El deseo de un burro valiente que "Quería pisar tierra, una vez"32 y se llevó consigo a todos los niños en su delirio.

"Tu hijo fue a la guerra al lomo de un burro: el Mariscal. / Un burro de la historia. / Leyó todo mal. Todos los signos mal. / Fue al muere"33. Terminado el poemario, y la guerra, ésta aún continúa, continúa como "guerra mental" incluso en el imperio pacificado del comercio mundial. Por eso, para este poemario, la guerra no termina en la guerra. "La guerra es la continuidad de la guerra" ${ }^{34}$, la supervivencia latente que perdura en el presente y opera en aquello que funda como la "conciencia etérea de una riña". Separada del campo de batalla, la contienda continúa en una "guerra mental que se libra más allá del tiempo, en nuestras imaginaciones", en nuestros cuerpos, en nuestras 
afecciones, en nuestra lengua, en nuestros modos de lectura y de pensamiento, mientras hacia afuera "extendemos el campo de la paz, del orden, de la administración" 35 , otro modo de violencia soterrada.

En Lampiñ, el referente histórico político es otro. Dedicado a la Columna Norte ${ }^{36}$, el poemario traza el exilio por los valles del personaje homónimo, expulsado por una guerra fratricida: "decirlo desde el principio: / al final las guerras (las guerras familiares, / o las guerras de guerrilla) / de la casa hacen un templo / que pronto decide su expulsión / en consenso de espíritus: / lampiño queda afuera"37. Aquí la guerra cobra una dimensión diversa, aunque no tanto. Es el Estado nuevamente el que decide la legitimidad de un combate, esta vez expulsando a la clandestinidad cualquier otro uso de violencia emancipadora que contradiga lo por él dispuesto:

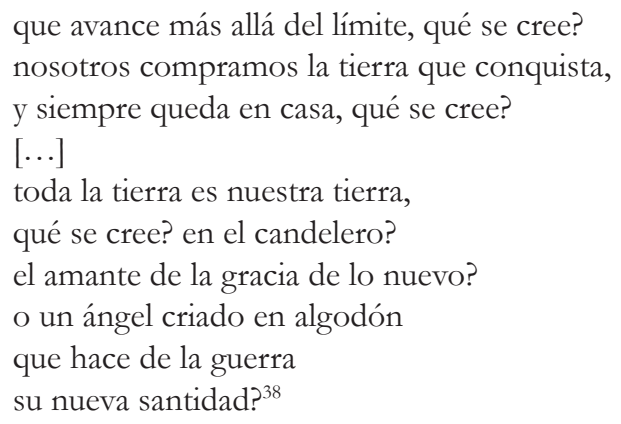

Lampiño queda afuera; "lampiño en patas, lampiño el del sueño crecido" vaga y canta, ahora en la intemperie, con la guitarra de otras peñas ${ }^{39}$. Al exilio del cuerpo sintiente ["lampiño con el cuero desflecado / [...] / la piel y la carne no existen, / solo el cráneo, el pelo no existe, / piedra y hueso..."40] le sigue ahora el exilio impuesto por una teología-política que historiza el monoteísmo del dios-padre-uno en el líder que reparte, a picotazos, las voces y los lugares usufructuando "el grito de los tordos que tapan los tiros / para reivindicar la naturaleza de todo esto" $"$.

Exiliado a la intemperie Lampiño culmina con un poema que dice así: “¿Había árboles afuera, Lampiño? No, había tierra / ¿Había un pueblo? / No, había tierra / ¿Había gente, y animales? / No, había tierra / desierta / bíblica"42. Siguiendo con la narratividad que suponíamos al principio podríamos decir que, al final de la guerra fratricida, lo que queda es una tierra desierta, al mismo tiempo vacía y abierta a un recomienzo otro de lo posible.

Sin embargo, Ministerio de desarrollosocial comienza, en cambio, inscribiendo esta apertura en una nueva opción dicotómica. Dice, a modo de epígrafe: "Estado y llanura, papaíto!"43. Como dijera Rodríguez en el artículo "Sol de noche" publicado en la
35. RODRÍGUEZ, Martín Orden y progresismo, 2014, p. 154.

36. Las referencias históricas al enfrentamiento entre el peronismo y Montoneros también pueden rastrearse en otro poema, en donde se menciona la estación Morris, sede del enfrentamiento policial en el que murieron dos de los fundadores de esta última organización. Para más referencias ver RODRÍGUEZ, Martín. Lampiño, 2004, p. 57.

37. Ibídem, p. 15.

38. Ibídem, p. 16.

39. En "Otra vuelta a la ida: la (in) estabilidad del lazo nacional en dos coyunturas poéticas. Lectura de Lampiño de Martín Rodríguez en la estela martinfierrista", M.

L. Romano piensa este poemario como una reescritura de La ida de Martín Fierro. Allí donde en el texto de 1872 se relataba la "expulsión de la casa y la familia que sufre el gaucho a causa de las guerras de fronteras; un regreso a la constricción a vivir a la intemperie, en el campo, fuera de la ley, para salvar el propio cuerpo de la vejación que infringe el Estado", el poemario de Rodríguez narra otra expulsión: la de "Montoneros de Plaza de Mayo el $1^{\circ}$ de Mayo de 1974, cuando Perón elige claramente por la derecha del peronismo". Lo que era "voz oída" del gaucho en el canto (habilitada por la prestación del cuerpo a la guerra), en Rodríguez, en cambio, deviene voz silente que indicaría la negación de esa voz realizada por el líder, voz que sólo fue útil durante la proscripción del peronismo pero que a su regreso fue expulsada y silenciada. Romano indica que lo que allí se disgrega es una 
"fraternidad corporizada", la del peronismo, inaugurando contra la ley primera martinfierrista ('los hermanos sean unidos') una guerra civil fratricida que expone la inconsistencia del lazo nacional. Cf. ROMANO, María Laura. "Otra vuelta a la ida", 2007.

40. RODRÍGUEZ, Martín. Lampiño, 2004, p. 13.

41. Ibídem, p. 61.

42. Ibídem, p. 70.

43. RODRÍGUEZ, Martín. Ministerio de desarrollo social, 2012, p. 4.

44. RODRÍGUEZ, Martín. "Sol de noche", 2014.

45. Ibídem.

46. RODRÍGUEZ, Martín. Ministerio de desarrollo social, 2012, p. 4.

47. Ibídem, p. 10.

48. Ibídem, p. 11.

49. Ibídem, p. 7.

50. Ibídem, p. 12. revista Crisis, lo que la guerra fue como obra pública transmuta ahora su poder, en democracia, a un ministerio "piadoso de relevo y conquistas de territorio" que traza su "gira mágica y misteriosa por el terreno que dejó la crisis" ${ }^{44}$. Se delinea, entonces, otro modo de conjunción teológico-militar para que el Estado "corte la maleza social y permita que el ministerio penetre el territorio" 45 , ponga el cuerpo y cree cuerpos: "Tallaste dentro / la estatuilla de un albino / que se derrite al sol, / / déjame estar / a las puertas / del Ministerio de Desarrollo Social, / / una solución / para los problemas laicos ${ }^{\prime 46}$.

En un tono de escritura bastante más narrativo e irónico que el de sus otros libros, Rodríguez pareciera trazar el tránsito que va de la violencia política del orden y el progreso a la del progresismo. Y lo hace escandiendo el libro en seis apartados que, podría pensarse, señalan a la vez el objetivo y el plan de acción de este brazo del estado: "bienestar social", "territorialidad", "reducción de daño", "experiencia de campo", "programa de la economía social" y "empoderamiento".

En el primero de ellos, "Bienestar social", la escritura avanza por frases espejadas que se duplican negadas, ambivalentes ["El que ama al Estado, se ama a sí mismo", "El que ama al estado, se odia a sí mismo" ${ }^{47}$ y, por frases tachadas, que enuncian la continuidad velada entre los funcionarios de este nuevo ministerio democrático y su pasado bélico, militar y totalitario: "En las oficinas no hay aire acondicionado / porque cada funcionario es un frío / calor. / Ex Gas del Estado. / Ex SOMISA. / Ex ATC. / Ex Barrio Roca. / Ex Esma. / Todas unidades de ejecución. / El hilo que une a Joan Báez con Hu Jin Tao / es el hilo dorado de la prosa del Estado"48.

En este apartado surgen, también, los dos personajes que serán centrales a lo largo de todo el libro. Por un lado el albino, nacido "de la copulación silenciosa y nocturna / del estado con el individuo. De esa violación / imperceptible" ${ }^{49}$; por el otro, el de la trabajadora social, nueva figura-madre hecha a imagen y semejanza de ese cuerpo creado por el estado. Un poema titulado "informe de situación" 50 delinea el modo en que se dará esta relación de "amor de arriba hacia abajo":

Los trabajadores sociales son los psicólogos para pobres.

La educación popular es la educación formal para

pobres.

Dice: los pobres no tienen inconsciente.

Se les voló. Se les volaron las chapas.

Dice: los pobres no tienen representaciones.

Cómo se llama el que guía el estado de necesidad?

Trabajador social. ${ }^{51}$

51. Ibídem, p. 9. 
En el segundo apartado, las trabajadoras sociales vueltas madres-vírgenes-misericordiosas [o, "Madre-Pueblo-Corazón"52] entran al territorio, con un nuevo "Evangelio" que reza así:

Todos los pobres son buenos. Todos los pobres son buenos.

- Ok, reconozco mi derrota ante el alcohol— dice uno.

Todos los pobres son buenos. Todos. Sin excepción.

-Estoy re loco- dice uno.

Ronda de pobres en el SUM.

La trabajadora social abraza lo que sueña: abraza al

violador, al pedófilo, al que hirvió

la mamadera y se le enchufó la boca, al que quemó

el colchón, y al que dijo que vio a Cristo en la aureola de

meo del colchón mientras

se quemaba, la trabajadora social abraza

al que le pide una entrevista en el CESAC 22,

y ella lo abraza porque abraza a absolutamente toda

la carne sufriente de la República Argentina, que incluye

-obvio-

a extranjeros..$^{53}$

53. Ibídem, p. 19.

Las trabajadoras sociales serán, entonces, estas nuevas enviadas de la milicia cristiana y democrática encargadas de trabajar, en el tercer apartado, por la "reducción de daño" en territorio. Una y otra vez ellas afirman (parafraseando irónicamente el verso que insiste en Crawl de Viel Temperley): "Vengo del barrio y estoy de éxtasis" 54 , "vengo de la escuela rural y estoy en éxtasis" 55 . Y aquí la reducción del daño, comienza y termina con una amputación del cuerpo ["el trabajo social es un lento armisticio del cuerpo / hasta que los pobres lo queman"56], con el despliegue de un "abanico de alambres de púa en el que internaron el / cuerpo y lo metieron para dentro" 57 . Rodríguez pareciera indicar que el trabajo político del ministerio hace carne en el cuerpo de sus enviados esa idea de "revolución que aspira a que no nazca nada. / Crezca nada. / Un mundo viejo gobernando lo de siempre" ${ }^{58}$. Idea que aparece redoblada en la imagen insistente de los trabajadores sociales: "Una pareja que se castró y mutiló y que fue donando / su humanidad lentamente en forma de carne, de / miembros, de cera, de leche seca y arroz sobre un / plato de loza al que vienen a picar las palomas / blancas de la paz social" ${ }^{19}$.

La imagen de esa entrega del cuerpo en forma de carne reaparece en el cuarto apartado, "experiencia de campo", como un dictum que prepara lo que será el "programa de la economía social", del quinto apartado: "La fuerza de los que aman la pobreza / se representa / con un gran puño de carne picada"60. La economía tiene, ahora, un nuevo "Génesis / en el principio fue el oficio, fue la mano creadora" ${ }^{" 11}$ nuevos apóstoles que bajan “cada mañana al pesebre barrial del Pueblo / Argentino con su

54. Ibídem, p. 19.

55. Ibídem, p. 87.

56. Ibídem, p. 29.

57. Ibídem, p. 30.

58. Ibídem, p. 34.

59. Ibídem, p. 30.

60. Ibídem, p. 47.

61. Ibídem, p. 51. 
62. Ibídem, p. 52.

63. Ibídem, p. 56.

64. Ibídem, p. 72.

65. Ibídem, p. 83. bisturí oxidado de ciencia social, / con su Mao, con su Marx, con sus fotocopias de / cursillistas sobre prevenciones de salud reproductiva" ${ }^{62}$ y un nuevo Padre:

Padre Francisco bendice herramientas que pidió a cada vecino desocupado o sub-ocupado (martillo, lija, taladro, gubia, sierra caladora, etc.)

y las puso sobre un lienzo amarillo con imágenes andinas.

Arrojó agua para su bendición, Coca Cola para su desoxidación y oraciones para la liberación.

Todos chochos con las herramientas nuevas de la construcción. ${ }^{63}$

El "empoderamiento" constructivo del último apartado, viene entonces bendecido por el mensajero que impone el orden por la paz, administra los lugares asignados y reza para que no nazca nada nuevo:

Dice: ama la pobreza como a ti mismo.

Dice: presérvala en su pobreza.

Dice: ama al esclavo, el contacto directo de la humildad con Dios.

Dice: ya no somos una nación moderna.

$[\ldots]$

Etiqueta: siempre nace lo viejo. ${ }^{64}$

Su plegaria queda escrita en carbonilla al interior de la sala de espera del Ministerio: "La alegría infinita / del hombre que lleva / sus herramientas en la bicicleta. [...] El trabajo es un don, / no es explotación. / Ministerio de Desarrollo Social / de la Nación. / Todo esto no existe. Es imaginario puro. / Puro, duro, duro, duro, duro" $" 65$.

De manera singular y teniendo como referente acontecimientos histórico-políticos diversos, cada uno de estos libros modula y expone el modo en que la violencia política opera un reparto soberano de los cuerpos, los afectos y las lenguas. A un reparto teológico-político que, "en el nombre del padre", excluye los cuerpos sintientes para hacer de ellos carne útil, sacrificable y equivalente (para someter, en suma, por la 
guerra, lo heterogéneo bajo su orden soberano y fundante), le sigue luego un reparto teleológico que somete lo heterogéneo de las experiencias del tiempo a una filosofía de la historia del capital (o sea, del Estado liberal). A la crítica del orden y del progreso, Rodríguez suma luego la del progresismo que, mediante un relato piadoso construido de arriba hacia abajo, concibe los cuerpos (pobres) como carentes de inconsciente y de representaciones. Al ya trazado hurto de los cuerpos, de sus voces y sus dimensiones afectivas le sigue ahora el hurto del imaginario, de la potencia de imaginación y simbolización de lo común, perpetuado por una violencia soterrada y pedagógica (democrática y neoliberal) que, como afirmara Rancière en $E l$ espectador emancipado, busca suprimir la distancia entre el saber y la ignorancia, entre la potencia y la impotencia y no hace más que reproducirla incesantemente (condición necesaria para que el Ministerio de desarrollo social no cese de existir).

Contra una lectura progresiva y excepcionalista de la historia, su poética expone -como dijera Sergio Villalobos - la continuidad de la violencia soberana y "su capacidad práctica para circunscribir la multiplicidad de la vida social, las formas heteróclitas de ser-en-el-mundo, a un relato interesado sobre el origen y el destino de la comunidad" ${ }^{\circ 6}$. Rodríguez desmonta la ficción soberana y recorre, en "el hilo dorado de la prosa del Estado", la relación intrínseca entre derecho y vida, entre policía y política, entre Estado, soberanía y violencia. Hace la genealogía de las formaciones que inscriben la relación entre soberanía, cuerpo y capital para exponer, como dijera Agamben "un origen [que] no se sitúa solamente en un pasado cronológico [sino que] es contemporáneo al devenir histórico y no cesa de operar en éste" ${ }^{67}$. En las distintas modulaciones de esta relación (Guerra, Golpe de estado, o Gestión democrática neoliberal) lo que se indica es, como afirmara John Kraniauskas, la repetición continua de "la acumulación 'originaria', en la que la coacción violenta reconstituye formas y soberanías estatales $[\ldots]$, al mismo tiempo que redefine subjetividades políticas" ${ }^{\prime 68}$.

Pero en el contexto que despliegan estas diversas formas de garantizar que no "nazca nada" o que siempre "nazca lo viejo" la apuesta, entendemos, no es sólo la de exponer y criticar el sistema ordenado y monológico sino más bien la de mostrar, con la escritura, que todas las formaciones (estatales, institucionales, subjetivas y lingüísticas) poseen su fabulación de origen y que es allí donde radica al mismo tiempo su potencia efectiva y el punto ciego que abre la posibilidad de otro recomienzo posible. Donde se afirma un lenguaje técnico-político que, como dijera León Rozitchner ${ }^{69}$, acompaña y prepara el desarrollo del sistema económico (capitalista y liberal) y de los cuerpos fetichizados a su medida, Rodríguez opone otro modo de imaginación política,
66. VILLALOBOS-

RUMINOT'T, Sergio. Soberanias

en suspenso, 2013, p. 24-25.

67. AGAMBEN, Giorigio.

Desnudez, 2011, p. 26.

68. En Políticas literarias. Podery acumulación en la literatura y el cine latinoamericanos, John Kraniauskas recupera las consideraciones de Marx en torno a la "acumulación originaria" como pre-condición histórica del surgimiento del capital que opera por desposesión, para inscribirla ya no en un pasado originario, sino en un relato continuo, en el que el mismo gesto es repetido en cada instancia de reacomodo y refundación del capital.

Allí afirma: "la acumulación originaria, o primitiva, es una presuposición continua, más que una presuposición que se acaba con la emergencia del capitalismo como sistema, en cuyo caso tan sólo sería precapitalista. Desde esta óptica, la violencia de la acumulación originaria acompaña permanentemente a todos los regímenes de acumulación capitalista (industrial, no industrial, financiera), al grado que se podría hablar, en palabras de Roger Bartra, de procesos de "acumulación primitiva permanente”. KRANIAUSKAS, John. Políticas literarias, 2012 , p. 273-274.

69. León Rozitchner en La Cosa y la Cruz: Cristianismo y capitalismo rastrea el modo como la construcción histórica de una nueva subjetividad fue condición necesaria para el triunfo conjunto de la economía y la religión. Allí señala: "Se necesitó imponer primero por el terror una premisa básica: que el cuerpo del hombre, carne sensible y enamorada, fuese desvalorizado y considerado un mero residuo del Espíritu abstracto. Sólo así el cuerpo pudo quedar librado al cómputo y al cálculo; al predominio frío 
de lo cuantitativo infinito sobre todas las cualidades humanas. Creemos que el cristianismo, con su desprecio radical por el goce sensible de la vida, es la premisa del capitalismo, sin el cual éste no hubiera existido. Puesto que para que haya un sistema donde paulatinamente todas las cualidades humanas, hasta las más personalizadas, adquieran un precio -valor cuantitativo como "mercancía", forma generalizada de valorización de todo lo existente- fue necesario previamente producir hombres adecuados al sistema en un nivel diferente al de la mera economía. La tecnología cristiana, organizadora de la mente y del alma humana, antecede a la tecnología capitalista de los medios de producción y la prepara". ROZITCHNER, León. La cosa y la cruz, 2015, p. 34-35.

70. Si bien en este trabajo no nos adentramos de lleno en esta problemática, cabe aclarar que convocamos el horizonte categorial de lo "impolítico" -sugerido por Esposito (2006) y cartografiado por Hervás en el pensamiento filosófico contemporáneo (2003) - para pensar la imaginación política singular que despliega la poética de Rodríguez; imaginación que, sostenemos, no se homologa sin más a una perspectiva "antipolítica" sino que "se sitúa en la distancia crítica entre la despolitización moderna y la teología política" rechazando todo lugar trascendente de fundación de lo político (sea éste económico, jurídico o religioso) (ESPOSITO, Roberto. Categorías de lo impolítico, 2006, p. 27). En esta línea, cabe destacar, también, los aportes realizados por Karina Miller en Escrituras impolíticas, libro en donde la autora, haciendo uso de esta categoría y de manera próxima a lo que aquí "impolitica": imaginaciones plurales y de efectos incalculables, que usan la violencia para interrumpir y debilitar cualquier pensamiento enfático que se proponga otorgar un sentido a la vez verdadero, único y direccional. Traza, como dijera Rancière, otro montaje de palabras e imágenes, para construir con ellas heterotopías más que utopías, para reconfigurar lo perceptible y lo pensable bajo un nuevo régimen de significación que haga posible el diseño polémico de un paisaje otro de lo sensible, trazando entrelazamientos complejos de diversos regímenes de expresión sin una relación definida que garantice su eficacia o su interpretación. Adopta, en suma, como propone DidiHuberman ${ }^{71}$, una posición literaria, una posición ética y estética para batallar en el vasto campo común de conflictos que es la lengua.

Pero quizás allí quede por pensar una sutil diferencia entre una toma de posición ética de la poesía y una política de la poesía, en cuanto al menos en esta poética, a diferencia de otras, lo que se disputa es un empaste imaginario-político entre violencia, guerra y nación en un intento por proponer un montaje otro de la violencia. Una violencia intransitiva, como aquella que liberan las imágenes heterogéneas en colisión, la violencia de una palabra que recupera en ráfagas su posibilidad de ser cuenco capaz de gestar diferencias, de exponer otra relación posible de lo común, de recomenzar lo dado sin repetirlo sin más. La violencia de un deseo vital en donde Eros y Tánatos exhiben su potencia compleja y fluida a expensas del orden de los cuerpos que intenta fijarla en un estado simple.

Rodríguez trabaja sobre la violencia soberana pero para producir imágenes que fuguen y des-obren el trabajo de esa violencia fácilmente recuperable por el espectáculo o por la razón utilitaria, historicista, económica, jurídica o política. Si la violencia histórica trazó su estigma en el río teñido de rojosangre, un río que arrastra, al mismo tiempo, "la cuna en un bote, / las flores y las balas / por el río Paraguay"72, quizás debiéramos pensar que esta cita dice ya algo en torno al uso particular de la imagen que hace Rodríguez - parafraseando el título de otro de sus libros- "para el lado de las cosas sagradas". Pero para el lado de las cosas sagradas, tal como lo entiende Jean-Luc Nancy ${ }^{73}$, esto es: para el lado de lo distinto, de lo separado, de lo sustraído. Sabemos que para el filósofo toda imagen tira, saca, extrae algo, una intimidad, una fuerza. La distingue, la desata y la lanza hacia adelante y, en ese lanzamiento, hace su marca, su trazo. Y sabemos también que en este gesto se juega la ambivalencia misma de la violencia, aquella que es propia de la extracción y de la distinción. Y entonces: ¿pueden acaso figurarse imágenes de la violencia que no sean ellas mismas violentas?

Si en la cita del poema de Paniagua comparece la referencia de aquel pasaje bíblico del Éxodo en donde Moisés adquiere su nombre por haber sido justamente sacado del agua, de su cuna 
en el agua, quizás podamos pensar la apuesta de recomienzo imaginario de Rodríguez en colisión con este gesto. Porque Moisés, ese ser sacado del agua y vuelto "forastero en una tierra extraña", sabemos, se convierte luego en el indicado para sacar, él también, al pueblo israelita del yugo egipcio. Y debe hacerlo haciendo uso de una fuerza que lo trasciende y que sin embargo deberá poner fuera de sí, traer a la presencia, mostrar una imagen prodigiosa que legitime su potencia. Una de ellas es la de tomar agua del río y convertirla en sangre sobre el suelo, exponer una imagen violenta, o, más bien, "producir la muerte inmediatamente delante de sí en un charco material"74.

Pero si es cierto, como insiste en advertir Nancy, que "toda imagen, quizás, esté al borde de la crueldad", que "toda imagen está al borde de un charco semejante" ${ }^{75}$, la poética y la política de recomienzo de las imágenes que traza Rodríguez, creemos, quizás debiera leerse en el revés de este gesto. Ya no un convertir el río en sangre y hacer de ésta la imagen de su violencia y la revelación total de su potencia, sino al contrario: oponer a la imagen de la violencia, la violencia de la imagen, la violencia de un exceso de sentido que no revela ya más que su gesto, que no es índice de ninguna cosa fija, que no coagula en ningún significado. Quizás la apuesta sea, entonces, la de convertir la sangre coagulada en río, devolver su imagen violenta a un fluir líquido, a una secreción de sentido constantemente en movimiento. Trazar, en suma, un territorio imaginario donde la politicidad es siempre una política de frontera; una frontera líquida o etérea en donde todo recomienzo se expone como mezcla y no como fundación, novedad o revelación.

"Un solo ojo para ver el orden del mundo. / Con el otro ver el agua libre en el río, / la materia en la forma, / el cuerpo en la luz"76. Rodríguez vuelve la cuna al río y extrae, entonces, de "entre las piedras, una sonrisa / a la intemperie" 77 , saborea como frutas mudas en su boca palabras nuevas que "escupió a secas" para decir: "así acaba el cuento / buscándole el pelo a todo, / quiero decirte algo: / lo que fuiste a buscar / tuvo un peso especial, y no tu peso pluma"78. Rodríguez repone el peso especial de esos cuerpos con una escritura musical que recupera en la palabra el pensamiento y la acción de quienes combatieron; de cuerpos sexuados, sintientes y deseantes, sedientos, en suma, no sólo de sentido racional sino también de una experiencia vital no alienada ni escindida en donde lo mítico y lo histórico convergen. Como dijera Santiago Llach, ese es "el modo de conocer de la poesía: antes que la fragmentación de la experiencia, la unidad, antes que la alienación, el contacto con la vida, antes que la saturación significativa de la ciudad heterogénea"79... recomienzos plurales, fluidos. Rodríguez vuelve al agua entonces para recomenzar de otro modo, para fabular otro origen del mundo posible. Y lo hace imaginando proponemos pensar, busca repensar la relación entre literatura y política "más allá del paradigma del 'compromiso' de los años sesentas y setentas en América Latina" (MILLER, Karina. Escrituras impoliticas,

71. DIDI-HUBERMAN, Georges. "Volver sensible / hacer sensible”, 2014, p. 93.

72. RODRÍGUEZ, Martín Paraguay, 2012, p. 27.

73. NANCY, Jean-Luc. "La imagen, lo distinto", 2014, p. 456-478.

74. NANCY, Jean-Luc. Au fond des images, 2003, p. 53.

75. Ibídem, p. 53.

76. RODRÍGUEZ, Martín.

Paraguay, 2012, p. 85.

77. Ibídem, p. 65.

78. Ibídem, p. 67.

79. LLACH, Santiago. "Algunas ideas en torno a Lampiño", 2004, p. 79. 
80. RODRÍGUEZ, Martín.

Paniagua, 2005, p. 51. porque sabe que en el agua no hay ningún sentido dado, sólo la potencia de hacer sentido, de simbolizarlo de otro modo: "En el agua no se lee, en el agua se escribe"

Cuando se cierra el sentido, la apuesta de Rodríguez es la de volver a imaginar el principio, el origen (el arché) que es menos un origen irrecuperable, incognoscible y perdido que un origen que se conquista en la lengua y como poema porque aún opera en el presente. Un origen que se traza en el pasaje entre la anterioridad prenatal y la posteridad histórica y recomienza desde allí su estado fluido, primitivo, lúdico y anfibio.

Por contagio sonoro, su escritura imagina las escenas violentas y deseantes que se acumulan y arañan entre las palabras que quieren fijar su sentido. El agua se vuelve, entonces, origenciénaga, natatorio, hervidero, caldo seminal y germinal en el que fluyen y chocan sus fuerzas la política y el mito, lo prenatal y lo histórico, la lengua poética y la prosa del Estado. Contra el orden, el reparto y las clasificaciones, Rodríguez expone la potencia vital del con, que es menos de con-strucción, que de contagio, deriva de afecciones. Ante el triunfo de la lengua monológica y patriarcal, repone la potencia somática, continua y fluida de la lengua que, ventrílocua de la prosa del Estado, la pone a hablar de otro modo.

Si orden, progreso y progresismo signan en la lengua el triunfo de un orden monológico, bélico y pedagógico de los cuerpos y las voces, Rodríguez recomienza otra imaginación política y traza allí su política de la poesía. Porque sabe que toda guerra tiene como objetivo lo fluido (ya sea el río, la lengua, el deseo de los cuerpos o sus flujos), que todo régimen policial intenta detenerlo y liberarlo solo para el usufructo del capital. Si la escritura de Rodríguez toma posición en la lengua y hace de ella un nuevo campo de batalla, es para recomenzar el deseo de esa guerra popular que quedó aplastada por la soberanía del aparato, que siempre imagina su afuera como llanura desierta. A ese imaginario, Rodríguez le devuelve la imagen superpoblada de ese espacio que es su otro. Sobreimprime a la violencia económica, rentable (del capital, de la historia, de la política y de la guerra) una violencia an-económica: la del exceso incalculable de lo vital y del deseo.

En esta línea, al mundo viejo gobernando lo de siempre Rodríguez opone en otro de sus libros, Maternidad Sardá (2005), un brote de nacimientos y los instala en el centro de lo público. En el barrio de la maternidad, la dinámica del poema copia aquí la dinámica del parto y conquista su sentido menos en lo dicho que en el corte, en el pasaje que emula ese momento intenso del surgimiento en donde deseo y crueldad, vida y muerte confluyen en un fluir de líquidos de diversa densidad (orines, babas, flujos, sangre, leche). Como dijera Selci, el pathos del nacimiento se vuelve pasión pública y al mismo tiempo patología. 
En este poemario, una vez más, se afirma que "la sangre es una filiación cualquiera" 81 , que allí donde sabemos lo que nos falta se anuncia aún una tarea: imaginar ese origen, conquistar esa filiación en la lengua: “derramada la yema del huevo caliente, en la mirada de los otros. / Hallarse. Y nacer. En la mirada de los otros: empezar de nuevo" $\$ 2$. Rodríguez sabe que siempre se nace con otros, para otros, $a$ otros, como dijera Nancy. Sabe también que trazar la pluralidad originaria de orígenes es también exponer la apertura de un mundo, de esos múltiples mundos singulares, que surgen siempre cada vez, abriendo con ella la posibilidad de un modo otro de simbolizar el nosotros contemporáneo. Lo sabe y por eso traza su oración: “Oración / por un sueño en pañales / por un pañal con el puño / [...] / con su puño aferrado / a lo que todavía no existe, / con el mensaje del sexo en los labios"83.

De nuevo, su escritura es aquí cosmogónica, pero como afirmara Nancy "expresa la cosmogonía como lo que es: necesariamente plural, difractada, discreta, toque de color o timbre, frase o masa plegada, resplandor, aroma, canto o paso suspendido, ya que es el nacimiento de un mundo (y no la construcción de un sistema)" $" 84$. Aferrado al azar incalculable de los nuevos surgimientos, en el terror, la crueldad y la ternura que cobija esa construcción estatal envejecida, su poética afirma y celebra finalmente su existencia y la posibilidad con ella de los múltiples recomienzos en potencia que aún están por llegar. En última instancia Rodríguez, como los mineros, no sólo se interna en la roca dura de los lugares comunes para extraer algo nuevo sino que trabaja la roca dura de los lugares públicos para extraer de ellos lugares comunes, es decir, mundos.

\section{Referencias}

AGAMBEN, Giorgio. Desnudez: Traducción de Mercedes Ruvituso, María Teresa D’Meza y Cristina Sardoy. Buenos Aires: Adriana Hidalgo, 2011.

DELEUZE, Gilles; GUATTARI, Félix. Mil mesetas. Capitalismo y esquizofrenia. Traducción José Vazquez Pérez. Valencia: Pretextos, 2002.

DÍAZ, Marcelo. "Estoy completo, sé lo que me falta". Otra parte. n. 24, 2011, p. 47-50.

DIDI-HUBERMAN, Georges. "Volver sensible/ hacer sensible". In: BADIOU, Alain (et. al). ¿Qué es un pueblo? Traducción de Cecilia Gonzalez y Fermín Rodríguez. Buenos Aires: Eterna Cadencia Editora, 2014. 
ESPOSITO, Roberto. Categorías de lo impolitico. Traducción Roberto Raschella. Buenos Aires: Katz, 2006.

FONDEBRIDER, Jorge (Comp.). Tres décadas de poesía argentina. Buenos Aires: Libros del Rojas, 2006.

GALINDO HERVÁS, Alfonso. La soberanía. De la teología politica al comunitarismo impolitico. Murcia: Res Publica, 2003.

KRANIAUSKAS, John. Politicas literarias. Poder y acumulación en la literatura y el cine latino-americanos. México: FLACSO, 2012.

LLACH, Santiago. "Algunas ideas en torno a Lampiño". In: RODRÍGUEZ, Martín. Lampiño. Buenos Aires: Siesta, 2004.

"Poesía en los noventa: una aproximación". In: FONDEBRIDER, Jorge (Comp.). Tres décadas de poesía argentina. Buenos Aires: Libros del Rojas, 2006, p. 193.

MALLOL, Anahí "Para una sigilografía de los noventa". In: FONDEBRIDER, Jorge (Comp.). Tres décadas de poesía argentina. Buenos Aires: Libros del Rojas, 2006, p. 213.

MILLER, Karina. Escrituras impoliticas. Anti-representaciones de la comunidad en Juan Rodolfo Wilcock, Osvaldo Lamborghini y Virgilio Piñera. Pittsburgh: Nuevo Siglo, 2014.

NANCY, Jean-Luc. Au fond des images. París: Éditions Galilée, 2003.

. Ser singular plural. Traducción Antonio Tudela Sancho. Madrid: Arena libros, 2006.

. "La imagen, lo distinto". Traducción Gabriela Milone. Revista Caja Muda. n. 6, 2013. Disponible en: https://issuu. $\mathrm{com} /$ cajamuda/docs/issuun6completo.

NANCY, Jean-Luc ; BARRAU, Aurélien. Dans quels mondes vivons-nous? París: Éditions Galilée, 2011.

RANCIÈRE, Jacques. El reparto de lo sensible. Estética y politica. Traducción Patricio Mena e Iván Trujillo. Santiago de Chile: LOM ediciones, 2009.

. El espectador emancipado. Traducción Ariel Dilon. Buenos Aires: Manantial, 2011.

RODRÍGUEZ, Martín. Lampiño. Buenos Aires: Siesta, 2004. . Paniagua. Bahía Blanca: Gog y Magog, 2005. . Maternidad Sardá. Bahía Blanca: Vox, 2005. . Paraguay. Bahía Blanca: Vox, 2012. 

- Ministerio de desarrollo social. Buenos Aires: Determinado

Rumor, 2012.

. Orden y progresismo. Los años Kirchneristas. Buenos Aires:

Emecé, 2014.

. "Sol de noche". Revista Crisis, n. 19, 18 de julio de 2014.

Disponible en: http://www.revistacrisis.com.ar/notas/sol-denoche.

ROMANO, María Laura. “Aguas prohibidas: el paraíso perdido y las luchas federales en torno a la libre navegación de los ríos. Una lectura de Paniagua de Martín Rodríguez". El interpretador, n. 32, 2007.

" Otra vuelta a La ida: la (in)estabilidad del lazo nacional en dos coyunturas poéticas. Lectura de Lampiño de MR en estela martínfierriesta”. In: Actas del XV Congreso Nacional de Literatura Argentina, 2007.

ROZITCHNER, León. La cosa y la cruz. Buenos Aires:

Biblioteca Nacional, 2015.

SELCI, Damián. "Martín Rodríguez, o por qué mantener a la familia". Éxito. n.10, 2006.

VIEL TEMPERLEY, Héctor. Obra completa. Buenos Aires:

Ediciones del Dock, 2003.

VILLALOBOS-RUMINOTTT, Sergio. Soberanias en suspenso.

Neoliberalismo, Violencia e Imaginación. Lanús: La Cebra, 2013.

Submissão: $10 / 05 / 2017$

Aceite: $15 / 07 / 2017$ 